DOI: $10.2478 / \mathrm{v} 10025-012-0017-9$

JOURNAL OF WATER

AND LAND DEVELOPMENT

J. Water Land Dev. No. 15, 2011: 193-208

\title{
An assessment of the water requirements of a mountain pasture sward in the Polish Western Carpathians
}

\author{
Antoni KUŹNIAR, Stanisław TWARDY, Agnieszka KOWALCZYK, \\ Marek KOSTUCH
}

Institute of Technology and Life Sciences in Falenty, Małopolska Research Centre in Kraków, ul. Ułanów 21B, 31-450 Kraków, Poland, phone/fax +48 12 412-84-59, e-mail: a.kuzniar@itep.edu.pl

\begin{abstract}
The water requirements of the pasture sward using the Penman-Monteith method (FAO-56), which is seldom applied in Poland, was assessed. The reference crop evapotranspiration $E T_{o}$ from a hypothetical grass crop with an assumed crop height of $0.12 \mathrm{~m}$, a fixed surface resistance of $70 \mathrm{~s} \cdot \mathrm{m}^{-1}$ and an albedo of 0.23 , was used. These assumptions are similar under conditions of ruminant grazing. $E T_{o}$ was computed by using meteorological data from 43 weather stations. The crop evapotranspiration $E T_{c}$ is the product of $E T_{o}$, and single crop coefficient $K_{c}$. The differences between precipitation and $E T_{o}$ and $E T_{c}$ (climatic water balances) were determined for mountain pastures. The results were summarised form of a table and maps of isohyets and isolines elaborated by applying the Geographic Information System techniques (Arc View 9) with the data interpolated by the geostatic method (Kriging).
\end{abstract}

Key words: pasture sward, crop evapotranspiration, water requirements, the Carpathian Mountains

\section{INTRODUCTION}

The Carpathians is one of the most extensive mountain ranges of Europe stretching from Austria to Serbia. The Polish Carpathians cover an area of approx. $20,000 \mathrm{~km}^{2}$ and they are almost $300 \mathrm{~km}$ long (in W-E direction) and $50-100 \mathrm{~km}$ wide (in N-S direction) - between $49^{\circ} 45^{\prime} \mathrm{N}, 18^{\circ} 38^{\prime} \mathrm{E}$ and $49^{\circ} 18^{\prime} \mathrm{N}, 22^{\circ} 20^{\prime} \mathrm{E}$ ). In the west the area borders on the Czech Republic, in the south on Slovakia and partly on Ukraine and in the east on Ukraine. The northern border is estimated to be at approx. $50^{\circ} \mathrm{N}$. The Polish Carpathians are placed in the hypsometric range, starting from $300 \mathrm{~m}$ above sea level rising to almost $2500 \mathrm{~m}$ a.s.l. (the Rysy peak), in this mountain range forest and grassland prevails, meadows and pastures dominate on sites above an altitude of 550-600 m a.s.l. And with the increase of an elevation the patterns of agricultural land use changes. In the recent years arable land area has 
decreased of almost $40 \%$ and grasslands has increased of about $73 \%$ (TWARDY, 2008). Generally this is a favourable phenomenon, because in this way soil erosion is limited and soil-water environment is protected. The rearing of ruminants here is based on the utilization of large areas of permanent grassland as the main source of fodder.

However, in the mountain regions more consideration will be given to nonproductive roles, particularly in reference to high nature value (NNV) farming, erosion control, and aesthetic as well as landscape function. For pasture utilization we can distinguish the grass association of Lolio-Cynosuretum, which occurs in the whole area of the Carpathians. The remaining meadow-pasture groups (for example Heracio-Nardetum or Nardetum Carpaticum) have marginal economic importance because of very low yields and poor chemical and botanical composition of the swards.

Since the 25 percent of the Upper Vistula River basin $\left(50,732 \mathrm{~km}^{2}\right)$ is located in the Polish Carpathians, this river is a natural source of water for municipalities, industry and agriculture (DYNOWSKA and MACIEJEWSKI, 1991) Therefore, in considering the water supply of a river basin water consumed by natural vegetation becomes of increasing importance.

Studies conducted by ITP (IMUZ) at the research station Jaworki, at an altitude of $600 \mathrm{~m}$ a.s.l. (Małe Pieniny Mts.) showed that during farming of the mountain pastures, water deficits rarely occurred (KUŹNIAR and TWARDY, 2001). However, in a view of a great natural, hydrological and economical significance of those areas, and affirmed climatic changes, further studies are needed, by applying more precise methods.

Various methods have been used in the Polish Carpathians to determine the amount of water requirements of by agricultural crops and natural vegetation. The main methods are: lysimeter experiments, field experimental plots and soil moisture studies. However, the accuracy of recordings from small lysimeters is known to be not very high.

Evapotranspitation or consumptive use of water is the sum of two terms; (1) transpiration, which is water entering plant roots and used to build plant tissue or being passed through leaves of the plant into the atmosphere (2) evaporation, which is water evaporating from adjacent soil, water surfaces, or from the surfaces of leaves of the plant. And how temperature, humidity, wind velocity, vapour pressure and solar radiation influence crop water requirements use has been studied by several researches (BAC and ROJEK, 1982; JAWORSKI, 2004.). While the measurement of precipitation is relatively straightforward and there is a fairly dense network of observing stations in Poland.

However, the measurement of evapotranspiration is difficult undertaking because the rate of evapotranspiration varies greatly with the ease with which water is available to crops. This leads to the concept of potential evapotranspiration, introduced by PENMAN (1948) and THORNTWAITE (1948) and defined as "the amount of 
water transpired in unit time by a short green crop, completely shading the ground, of uniform height and never short of water". As a results, estimation of reference evapotranspiration in Poland was based on Penman's formula (PENMAN, 1948), computed from climatic factors of net radiation, temperature, wind and humidity (KĘDZIORA, 1995; ŁABĘDZKI, 1995; MISZTAL, 2000; ROGUSKI et al., 1988).

The Penman theory and his equation contributed greatly towards the better understanding of the process of evaporation. Because he combined the energy balance with the mass transfer method and derived an equation to compute the evaporation from an open water surface from standard weather records of sunshine, temperature, humidity and wind speed. However, the use of the Penman equation, was limited to calculation of evapotranspiration of well-watered short grass. This led many researches to an attempt to develop the evapotranspiration equation to take into consideration the specific characteristics of crops, soil, soil cover and soil moisture status. This so-called combination method was further developed by many researchers and extended to cropped surfaces by introducing resistance factors. Such equations have been presented by Doorenbos and PRUIT (1977), JAWORSKI (2004), MONTEITH (1965).

The FAO Expert Consultation on Revision of FAO Methodologies for Crop Water (May 1990) recommended the adoption of the Penman-Monteith combination method as a new standard for reference evapotranspiration and advised on procedures for calculation of the various parameters. The reference crop was defining as a hypothetical crop with an assumed height of $0.12 \mathrm{~m}$ having a surface resistance of $70 \mathrm{~s} \cdot \mathrm{m}^{-1}$ and an albedo of 0.23 , closely resembling the evaporation of an extension surface of green grass of uniform height, actively growing and adequately watered. The method overcomes shortcomings of the previous FAO Penman equation and provides a means of assessing the adequacy of water supply to crops grown in various climatological areas. From the amount and distribution of rainfall, periods of water surplus or water deficit can be identified, and the amounts of water surplus assessed.

The objective of this paper was to determine water requirements and the climatic water balance of pasture swards in the Polish Carpathians by applying the FAO Penman-Monteith method FAO-56 (ALLEN et al. 1998). This objective was achieved through:

- estimation of reference evapotranspiration $E T_{o}$ and climatic water balance $\left(P-E T_{o}\right)$

- elaboration of spatial distribution (maps) of reference evapotranspiration $E T_{o}$ and water surpluses $\left(P-E T_{o}\right)$;

- determination crop evapotranspiration $E T_{c}$ for pastures in the Polish Carpathians. 


\section{MATERIAL AND METHODS}

The FAO Penman-Monteith method (FAO-56) (ALLEN et al., 1994; 1998; 2005; 2006; KUŹNIAR, 2010; ŁABĘDZKI, 1999; SMITH 1992) was used to assess the evapotranspiration. The reference surface can be unambiguously determined, and provides consistent $E T_{o}$ values in all regions and climates. Grass is a well-studied crop regarding its aerodynamic and surface characteristics and is worldwide accepted as reference. The reference evapotranspiration $E T_{o}$ (grass) was calculated by the equation:

$$
E T_{o}=\frac{0.408 \Delta\left(R_{n}-G\right)+\gamma \frac{900}{T+273} u_{2}\left(e_{s}-e_{a}\right)}{\Delta+\gamma\left(1+0.34 u_{2}\right)}
$$

where:

$E T_{o} \quad$ - reference evapotranspiration, $\mathrm{mm} \cdot \mathrm{day}^{-1}$;

$R_{n} \quad$ - net radiation at the grass surface, measured or estimated, $\mathrm{MJ} \cdot \mathrm{m}^{-2} \cdot \mathrm{day}^{-1}$;

$G \quad-$ soil heat flux density, $\mathrm{MJ} \cdot \mathrm{m}^{-2} \cdot$ day $^{-1}$;

$T \quad$ - mean daily air temperature at $2 \mathrm{~m}$ height, ${ }^{\circ} \mathrm{C}$;

$u_{2} \quad-$ wind speed at $2 \mathrm{~m}$ height, $\mathrm{m} \cdot \mathrm{s}^{-1}$;

$e_{s} \quad-$ saturation vapour pressure, $\mathrm{kPa}$;

$e_{a} \quad-$ actual vapour pressure, $\mathrm{kPa}$;

$e_{s}-e_{a}-$ saturation vapour pressure deficit, $\mathrm{kPa}$;

$\Delta \quad$ - slope vapour pressure curve, $\mathrm{kPa}^{\circ} \mathrm{C}^{-1}$;

$\gamma \quad-$ psychrometric constant, $\mathrm{kPa} \cdot{ }^{\circ} \mathrm{C}^{-1}$.

The above equation uses standard climatological records of solar radiation (sunshine), air temperature, humidity and wind speed. To ensure the integrity of computations, the weather measurements should be made at $2 \mathrm{~m}$ (or converted to that height) above an extensive surface of green grass, shading the ground and not short of water. The program is available in spread sheet versions download from FAO internet site (FAO www.fao.org/nr/water/index.html) which permit for assessment of reference evapotranspiration $E T_{o}$ based on standard daily, 10-day or monthly meteorological data. By using the FAO Penman-Monteith definition for $E T_{o}$, the crop coefficients can be determined by relating the measured crop evapotranspiration $E T_{c}$ with the calculated $E T_{o}$, i.e., $K_{c}=E T_{c} / E T_{o}$.

The effect of both crop transpiration and soil evaporation are integrated into a single crop coefficient $K_{c}$. For most water balance studies, average crop coefficients are relevant and suitable. Relations between the crop evapotranspiration $E T_{c}$ and reference evapotranspiration $E T_{o}$ were establishes and expresses by the equation: 


$$
E T_{c}=K_{c} E T_{o}
$$

where:

$E T_{c}$ - crop evapotranspiration;

$E T_{o}$ - reference evapotranspiration;

$K_{c}-$ crop coefficient;

The following ranges the $K_{c}$ coefficients (depending on growing stage) are recommended by ALLEN et al. (1998):

- alfalfa hay $\left(0.40^{*}-0.95\right)$,

- clover hay $(0.40 *-0.90)$,

- ryegrass hay $(0.95-1.05)$,

- grazing pasture - rotated grazing $(0.40 *-1.05)$,

- extensive grazing $(0.30 *-0.75)$,

- turf grass - cool season (0.90-0.95).

$*$ Values at the initial stage of the growing season.

Cool season turf grass varieties include dense stands of bluegrass, ryegrass, and fescue.

The $K_{c}$ coefficients for pastures to be used in the Penman or Penman-Monteith equations were adopted to the Polish condition by LABĘDZKI (1999; 2006), MISZTAL (2000), ROGUSKI et al. (1988), OSTROWSKI et al. (2008), SZAJDA (2004). Their values of the $K_{c}$ coefficient apply to grazing pastures with hay yield (DM) about $8 \mathrm{t} \cdot \mathrm{ha}^{-1}$ ŁABĘDZKI (1999) and MiSZTAL (2000) above $4 \mathrm{t} \cdot \mathrm{ha}^{-1}$. Therefore, for the Carpathian conditions lower values of the $K_{c}$ (e.g. similar to extensive grazing) are more relevant.

The concept of potential evapotranspiration as applied in the climatic water balance of grasslands was first introduced by THORNTHWAITE (1948); THORNTHWAITE and MATHER (1955), MATHER (1959). Information on the water surplus, the amount by which the precipitation exceeds the water needs when soil is at field capacity is fundamental in any hydrological studies (MIODUSZEWSKI, 2006). In Poland it has been used in several modifications, as the difference between precipitation and reference evapotranspiration $E T_{o}$ and evaporation from free water and potential evapotranspiration (BAC and ROJEK, 1982; KASPERSKA-WOŁOWICZ and ŁABĘDZKI, 2006; ŁABĘDZKI, 2006).

In this paper the climatic water balance in the summer season (May-October) was estimated from the following equation:

$$
C W B=P-E T_{o}
$$

where:

$C W B$ - climatic water balance in given periods, $\mathrm{mm}$;

$P \quad$ - precipitation, $\mathrm{mm}$; 
$E T_{o}$ - reference evapotranspiration estimated by the Penman-Monteitha (FAO-56) equation, mm.

The positive values of the above balance mean the water surplus, whereas the negative results indicate the water deficiency.

In this work meteorological data from the collection of the Institute of Meteorology and Water Management, from the period of 1990-2005, were used as well as weather observation from the Institute of Technology and Life Sciences at Jaworki Research station (Małe Pieniny, in Pieniny Mts). The observations included average monthly data: daily maximum and minimum air temperatures, $T_{\max }$ and $T_{\min }\left({ }^{\circ} \mathrm{C}\right)$, air humidity (\%), sunshine (h), wind speed $u\left(\mathrm{~m}^{-1} \mathrm{~s}^{-1}\right)$ and monthly totals of precipitations. The collected meteorological data encompass the terrain of a great spatial-altitude diversification - from the weather station at the lowest location at Dobczyce $300 \mathrm{~m}$ a.s.1. and the highest Zakopane (857 m a.s.1.) and Kasprowy Wierch (1990 m a.s.1.) (Tab. 1). Introduction of the above information to the GIS Arc View 9.0 allowed for visualisation of the climatological station against a background of the map of the Carpathians within the upper Vistula River basin. The results were showed spatially by applying the Ordinary Kriging Global method with application of the Gaussian model. As the result of interpolation analyses, maps in raster forms were obtained. Finally raster maps were converted into isolynes which fulfils criteria of the GIS ArcView environment.

\section{RESULTS AND DISCUSSION}

The obtained results of the climatic water balance elements (reference and potential crop evapotranspiration on a monthly basis) were synthesised in the form of table and maps of mean seasonal values (May-October) from the period 19902005. The tabular data (Tab. 1) refer to the point values (43 meteorological stations). And maps of isohyets and isolines elaborated by applying the Geographic Information System techniques (Arc View 9) present interpolated data by the geostatic method (Kriging) (Fig. 1, 2, 3). It allowed for characterization of reference and potential crop evapotranspiration in particular physic-geographic regions of the Polish Carpathians. Hence, the numerical data obtained in an objective parametric manner describe the region consideration in view of precipitation surpluses and deficits.

The spatial distribution of mean reference evapotranspiration $E T_{o}$ in the summer season (Fig. 1, Tab. 1) shows that it increased from a minimum of $433 \mathrm{~mm}$ at Zakopane (Tatra Mts.) to reaching maximum of $538 \mathrm{~mm}$ at Bielsko-Biała (Beskid Zachodni Mts.). Lower values of $E T_{o}$ were observed in the Beskid Ślaski Mts (440 $\mathrm{mm})$ and in the Beskid Sądecki Mts. $(460 \mathrm{~mm})$. In the Bieszczady Mts. $E T_{o}$ ranged between 460-480 mm during the season. Crop evapotranspiration of pastures $E T_{c}$ it shows lower values and varies from $325 \mathrm{~mm}$ (Zakopane) to $404 \mathrm{~mm}$ (Bielsko B.) 
Table 1. Average seasonal climatic water balance (May-October) for pastures in the Polish Carpathians, reference evapotranspiration $\left(E T_{o}\right)$, crop evapotranspiration $\left(E T_{c}\right)$ - pastures $\left(E T_{c}=K_{c} E T_{o}\right)$, precipitation $P,\left(P-E T_{o}\right),\left(P-E T_{c}\right)$

\begin{tabular}{|c|c|c|c|c|c|c|c|c|}
\hline \multirow{2}{*}{$\begin{array}{l}\text { Meteorological } \\
\text { station }\end{array}$} & \multirow{2}{*}{$\begin{array}{c}\text { Altitude } \\
\text { m a.s.l. }\end{array}$} & \multicolumn{2}{|c|}{ Location } & \multicolumn{5}{|c|}{$\begin{array}{c}\text { Average climatic water balance }(\mathrm{mm}) \\
\text { of the mountain pastures (May-October) }\end{array}$} \\
\hline & & $\begin{array}{c}\text { latitude } \\
\varphi\end{array}$ & $\begin{array}{c}\text { longitude } \\
\lambda\end{array}$ & $E T_{o}$ & $E T_{c}$ & $P$ & $P-E T_{o}$ & $P-E T_{c}$ \\
\hline Dobczyce & 300 & $49^{\circ} 52^{\prime}$ & $20^{\circ} 04^{\prime}$ & 488,4 & 366,3 & 511,4 & 23,0 & 145,1 \\
\hline Sanok Trepcza & 305 & 4935 & 2211 & 483,6 & 362,7 & 594,1 & 110,5 & 231,4 \\
\hline Jastrzębia & 310 & 4947 & 2053 & 477,6 & 358,2 & 538,1 & 60,6 & 180,0 \\
\hline Dukla & 325 & 4933 & 2141 & 526,8 & 395,1 & 562,1 & 35,3 & 167,0 \\
\hline Łącko & 360 & 4933 & 2026 & 498,7 & 374,0 & 504,4 & 5,7 & 130,4 \\
\hline Maków Podhalański & 360 & 4943 & 1941 & 442,4 & 331,8 & 634,0 & 191,5 & 302,1 \\
\hline Baligród Mchawa & 371 & 4921 & 2217 & 488,0 & 366,0 & 611,0 & 123,0 & 245,0 \\
\hline Piwniczna & 379 & 4926 & 2042 & 447,1 & 335,3 & 619,7 & 172,6 & 284,4 \\
\hline Nowy Dwór & 380 & 4939 & 1909 & 456,8 & 342,6 & 571,3 & 114,5 & 228,7 \\
\hline Lesko & 386 & 4928 & 2220 & 503,7 & 377,8 & 558,1 & 54,4 & 180,3 \\
\hline Bielsko-Biała-Alek. & 398 & 4948 & 1900 & 538,2 & 403,7 & 657,7 & 119,5 & 254,0 \\
\hline Limanowa & 414 & 4942 & 2026 & 505,8 & 379,4 & 549,8 & 44,0 & 170,5 \\
\hline Terka & 445 & 4917 & 2225 & 498,1 & 373,6 & 669,7 & 171,6 & 296,1 \\
\hline Krościenko & 452 & 4926 & 2025 & 486,2 & 364,7 & 559,7 & 73,5 & 195,1 \\
\hline Komańcza & 470 & 4920 & 2203 & 443,6 & 332,7 & 609,2 & 165,5 & 276,4 \\
\hline Leszczowate & 480 & 4930 & 2232 & 506,0 & 379,5 & 579,3 & 73,3 & 199,8 \\
\hline Wisła Głębce & 480 & 4937 & 1852 & 489,6 & 367,2 & 710,3 & 220,7 & 343,1 \\
\hline Rabka & 511 & 4936 & 1958 & 444,6 & 333,5 & 577,6 & 132,9 & 244,1 \\
\hline Wysowa & 519 & 4926 & 2110 & 468,2 & 351,1 & 591,5 & 123,3 & 240,4 \\
\hline Ptaszkowa & 520 & 4920 & 2053 & 459,4 & 344,5 & 599,1 & 139,7 & 254,5 \\
\hline Niedzica & 534 & 4925 & 2018 & 441,4 & 331,1 & 532,4 & 91,0 & 201,3 \\
\hline Rozdziele & 545 & 4948 & 2027 & 478,5 & 358,9 & 582,5 & 104,0 & 223,7 \\
\hline Sidzina & 553 & 4937 & 1944 & 451,0 & 338,3 & 565,3 & 114,3 & 227,0 \\
\hline Łopuszna & 568 & 4928 & 2007 & 463,0 & 347,2 & 533,7 & 70,7 & 186,5 \\
\hline Bartne & 578 & 4933 & 2121 & 506,2 & 379,7 & 614,2 & 108,0 & 234,6 \\
\hline Krynica & 585 & 4925 & 2058 & 447,7 & 335,7 & 572,4 & 124,7 & 236,6 \\
\hline Jaworki & 600 & 4925 & 2030 & 462,3 & 346,7 & 602,9 & 140,6 & 256,2 \\
\hline Zawoja & 615 & 4937 & 1931 & 490,8 & 368,1 & 745,1 & 254,3 & 377,0 \\
\hline Jabłonka & 620 & 4928 & 1943 & 441,7 & 331,2 & 492,0 & 50,3 & 160,7 \\
\hline Lachowice & 620 & 4942 & 1925 & 477,6 & 358,2 & 661,2 & 183,6 & 303,0 \\
\hline Laliki & 680 & 4932 & 1900 & 444,1 & 333,0 & 601,0 & 156,9 & 267,9 \\
\hline Wetlina & 708 & 4908 & 2228 & 477,0 & 357,8 & 720,3 & 243,3 & 362,5 \\
\hline Rycerka Górna & 710 & 4925 & 1901 & 424,9 & 318,7 & 723,3 & 298,4 & 404,6 \\
\hline Istebna-Kubal. & 780 & 4936 & 1854 & 438,4 & 328,8 & 727,8 & 289,4 & 399,0 \\
\hline Obidowa & 805 & 4932 & 1958 & 442,2 & 331,7 & 601,2 & 159,0 & 269,5 \\
\hline Zakopane & 857 & 4918 & 1957 & 432,9 & 324,7 & 774,9 & 342,0 & 450,2 \\
\hline Leskowiec & 870 & 4948 & 1927 & 453,1 & 339,8 & 701,0 & 247,9 & 361,2 \\
\hline
\end{tabular}




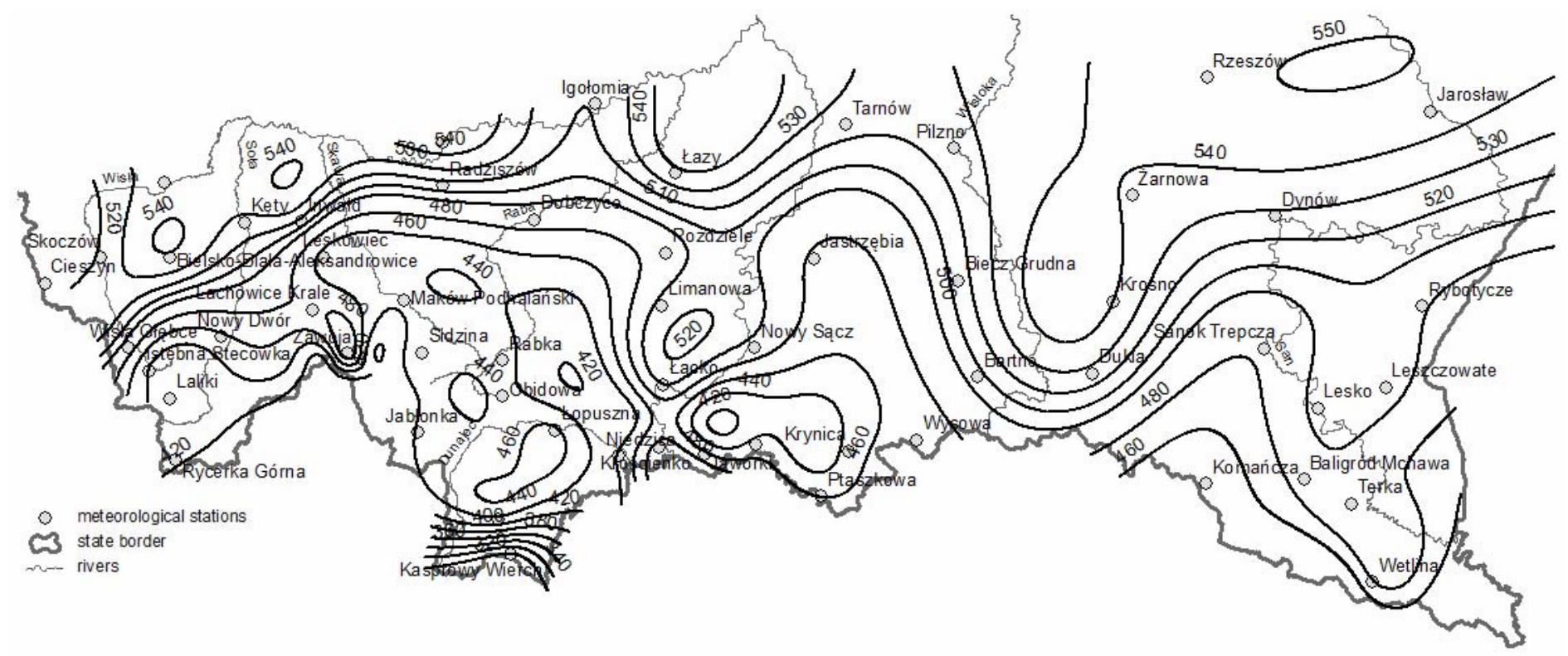

Fig. 1. Map of the Polish Carpathian showing isolines of average reference evapotranspiration - grass $\left(E T_{o}, \mathrm{~mm}\right)$, according to the FAO-56 Penman-Monteith method during the period May-October from 1990 to 2005 


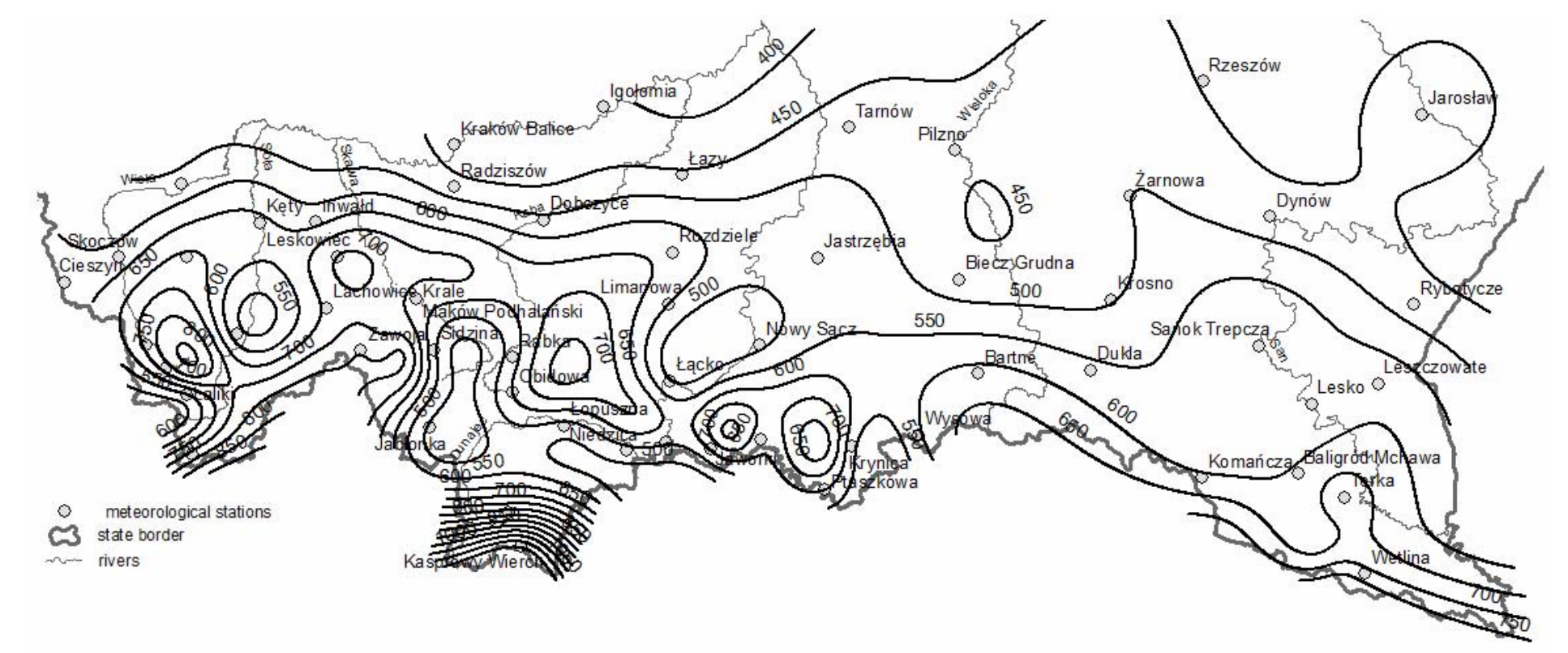

Fig. 2. Map of the Polish Carpathians showing isohyets of average precipitation totals $(P, \mathrm{~mm})$ during the period May-October from 1990 to 2005 


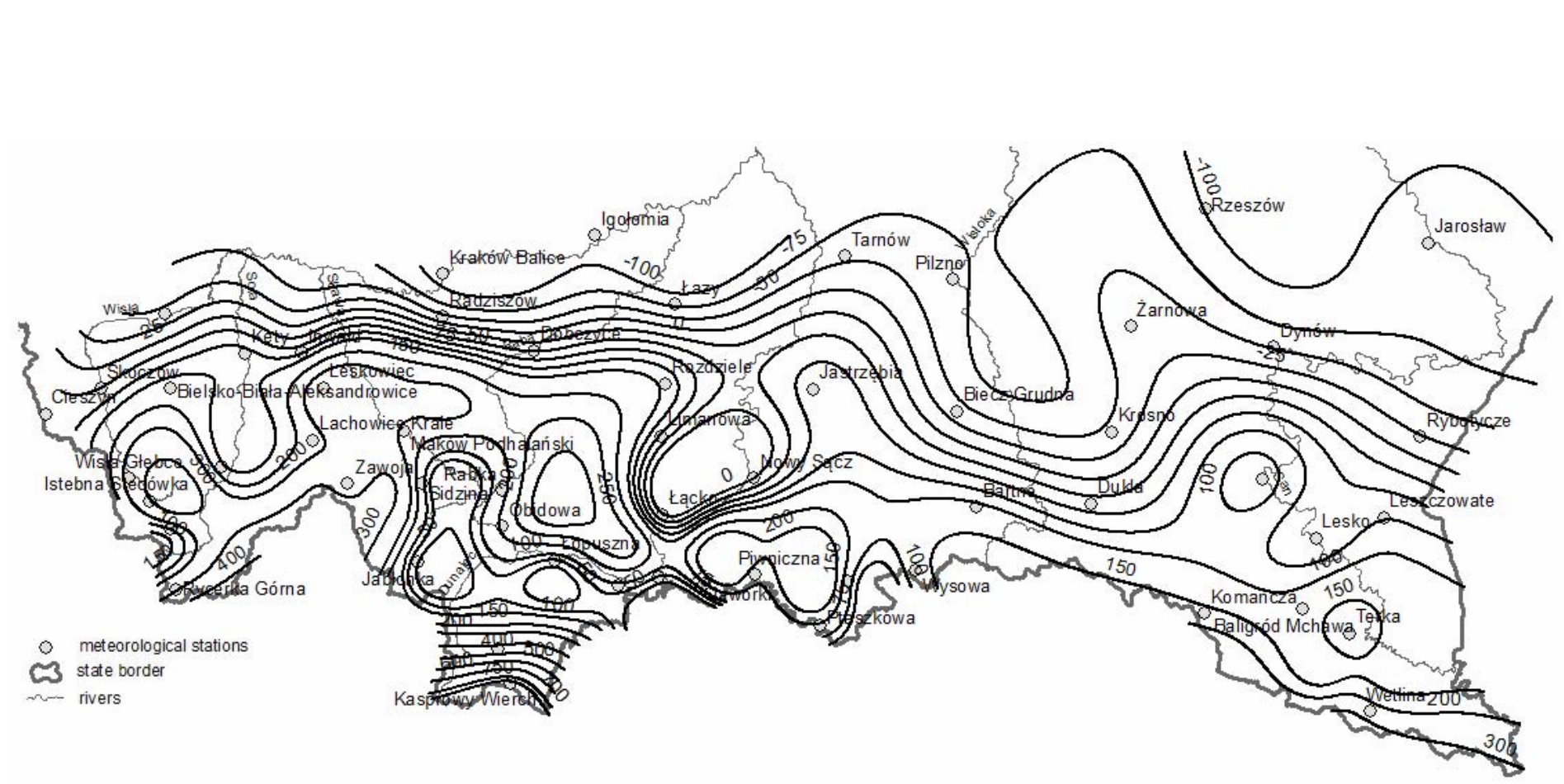

Fig. 3. Map of the Polish Carpathian showing isolines of average climatic water balance $\left(P-E T_{o}, \mathrm{~mm}\right)-$ water surplus and deficit - during the period May-October from 1990 to 2005 
(Tab. 1). Lower values of $E T_{c}$ were results of applied reduction factor $<1$ the $K_{c}$ coefficient $\left(K_{c} E T_{o}\right)$.

Comparing the values of reference evapotranspiration $E T_{o}$ the summer seasons estimated in the Carpathians in by various writers (by different methods), one may conclude that reference evaporation according to the Bac formula (BAC and ROJEK 1982) gave the lowest amounts $(360-410 \mathrm{~mm})$ Whereas mean values of $E T_{o}$ in summer season obtained by the Penman Monteith method (FAO-56) were higher, $505 \mathrm{~mm}(425-570 \mathrm{~mm}$ and they are rather close to results from van Bavel equation.

The highest precipitations in summer season (May-October) are falling in the Tatra Mts. Kasprowy Wierch $(1087 \mathrm{~mm})$ and Zakopane $(775 \mathrm{~mm})$. Above $700 \mathrm{~mm}$ of precipitation are received in the Beskid Ślaski Mts. (Istebna $-728 \mathrm{~mm}$ ) and the belt of Babia Góra Mts. (Zawoja - $745 \mathrm{~mm}$ ). Similar seasonal precipitation values are observed in the Bieszczady Mts. (Wetlina $-720 \mathrm{~mm}$ ). Along the footsteps of Beskids Mts. run isohyets of $550 \mathrm{~mm}$ and isohyets $450 \mathrm{~mm}$ is overlapping with the border of the Carpathian Foothill belt (Fig. 2).

Seasonal (May-October) totals of the climatic water balances $\left(P-E T_{o}\right)$ are characterized by great spatial differences: they are in a range from 6 to $343 \mathrm{~mm}$ and they did not reach negative (deficit) values in the Polish Carpathian.The highest precipitation surpluses $\left(P-E T_{o}\right)$ occur in the peak parts of the Beskid Żywiecki Mts. and in Polish Tatras (Zakopane $342 \mathrm{~mm}$ ). In the Beskid Wyspowy Mts. precipitation surpluses amounted from 100 to $250 \mathrm{~mm}$ and near the Sieniawska Gate above $200 \mathrm{~mm}$. Considerable water surpluses are also in the valleys: e.g. the Saqecka Valley (150-200 mm). In the Bieszczady Mts. the climatic water balance in summer period is in the range $150-300 \mathrm{~mm}$.

It has been found that the equilibrium isoline between precipitation and reference evapotranspitation $\left(P=E T_{o}\right)$ run along the border between the Carpathians and the Valleys. Earlier, results obtained ROJEK (1995) who showed that in analysed region the similar isoline, which designated the border between surplus and deficit areas (in relation to $E T_{o}$ ). According to BAC and ROJEK (1982) the climatic water balance $\left(P-E T_{o}\right)$ in the Carpathins - summer period was in the range between 120 and $210 \mathrm{~mm}$. KOWANETZ (1999) estimated the climatic water balance for summer season $(\mathrm{V}-\mathrm{X})$ in the Skawa Raba and Dunajec (the Polish Carpathians). And the water surpluses were from about $700 \mathrm{~mm}$ (Tatra and Beskid Żywiecki Mts.) to 100-200 mm (the Middle Beskid and Wyspowy Beskid Mts.).

Comparing spatial distribution of $\left(P-E T_{o}\right)$ and $\left(P-E T_{c}\right)$ in the Carpathians estimated by the Penman-Monteith (FOA-56) with the results obtained by other authors (BAC, 1982; KOWANETZ, 1999) it is clear that their negative values are larger and the surpluses in lower parts of the Carpathians are smaller, and they do not reach $150 \mathrm{~mm}$. It means that by applying in the water balance estimation, higher values of reference or crop potential evapotranspiration lead to underestimation of precipitation surpluses, problem on which many years ago drew attention BAC and ROJEK (1979). Similar situation can be in the case of determination of reference 
evapotranspiration by the original Penman method which overestimates the values as compared to recommended the Penman-Monteith method (FAO-56).

Analyses of spatial distribution of $E T_{o}$ and $P$, as well as the climatic water balance $\left(P-E T_{o}\right)$ in the summer period showed a good relationship among these elements and with an elevation above sea level $h$ (Tab. 1). For example the climatic water balance correlated with elevation $h$ (Fig. 4).

$$
P-E T_{o}=0.63 h-216.19, \text { with } R^{2}=0.732
$$

\begin{tabular}{lr}
\hline \multicolumn{2}{c}{ Regression statistics } \\
\hline Multiple $R$ & 0.856 \\
$R^{2}$ & 0.732 \\
Matched $R^{2}$ & 0.729 \\
Standard error & 67.852 \\
Observations & 83 \\
\hline
\end{tabular}

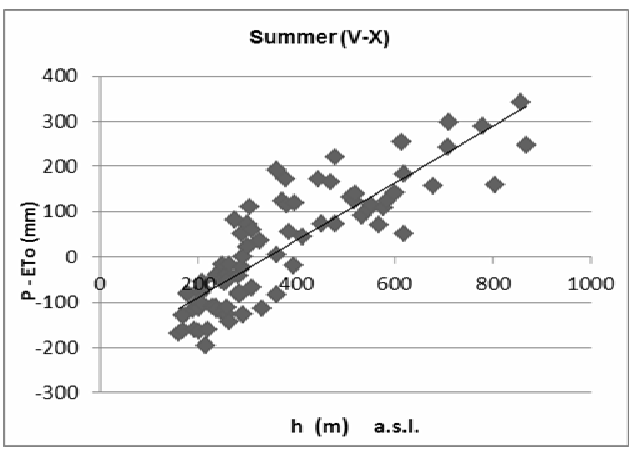

\begin{tabular}{lcccccc}
\hline & Coefficients & Standard error & $t$-test & Lower 95\% & Upper 95\% \\
\hline Intersection & -216.187 & 17.453 & -12.387 & -250.913 & -181.461 \\
Variable X1 & 0.632 & 0.042 & 14.872 & 0.547 & 0.716 \\
\hline
\end{tabular}

Fig. 4. Relationship between the climatic water balance $\left(P-E T_{o}\right)$ and an elevation $h$ a.s.l. - long term averages from the period 1990-2005, for the summer season (May-October)

In Poland for assessment evapotranspiration, the water balance method is adopted, although possibilities of its applications are limited to include an average value which is highly insufficient. Moreover, there is a risk of inadequate accuracy of precipitation measurements, which in a principal way influence the results of evaporation estimated by the hydrological equation.

Until now the FAO-56 Penmana-Monteith method has not been applied in the Polish Carpathians for evaluation of evapotranspiration of grasslands and pasture. It has resulted from the fact that these evaporation issues in the mountain and foothill areas are poorly distinguished, as compared with the remaining part of Poland. Furthermore, in relation to the previous calculation formulae, which were applied in the study area, the method makes up a successive stage in gathering data of the components of climatic water balance. An advantage of this method is the possibility of calculating the reference evapotranspiration using standard measurements originating from a meteorological station.

Studies have shown that the FAO-56 Penman-Monteith method which was applied in the Polish Carpathians facilitated computation in a reliable way, refer- 
ence evapotranspiration $E T_{o}$ and potential crop evapotranspiration for grasslands (pastures) $E T_{c}$ using readily available computer programs FAO-PM, for larger areas, including complete catchment areas.

The maps of isohyets and isolines which were drew out can be used for an approximate evaluation of the water balance components, particularly in situations when there is a lack of direct measurements. Linear relationship between elevation above sea level and analysed climatic water balance components (May-October) were significant $\left(R^{2}>0.7\right)$. This relation can be applied for assessment of mean values of ( $E T_{o}$ or $E T_{c}$ - rainfall relationship) in the Carpathians when there is lack of weather observations. It also can be used in cartography and classification of climates.

\section{REFERENCES}

1. Allen R.G., Smith M., Pereira L.S., Perrier A., 1994. An update for the definition of reference evapotranspiration. ICID Bulletin 43, 2: 1-92.

2. Allen R.G., Pereira L.S., Raes D., Smith M., 1998. Crop evapotranspiration: Guidelines for computing crop water requirements. Irrigation Drainage Paper, 56. Rome, FAO: 1-300.

3. Allen R.G., Clemmens A. J., Burt C. M., Solomon K., O’Halloran T., 2005. Prediction accuracy for project wide evapotranspiration using crop coefficients and reference evapotranspiration. Irrigation Drainage Engineering, 131, 1: 24-36.

4. ALLEN R. G. et al., 2006. A recommendation on standardized surface resistance for hourly calculation of reference $E T_{o}$ by the FAO-56 Penman-Monteith method. Agricultural Water Management. 81: 1-22.

5. BAC S., RoJeK M., 1979. Klimatyczny bilans wodny a odpływy w Polsce. (Climatological water balance and runoff in Poland). Przegląd Geofizyczny, 14 (32), 3-4: 293-298.

6. BaC S., RoJeK M., 1982. Klimatyczne podstawy bilansów wodnych w Polsce. In: Agroklimatyczne podstawy melioracji wodnych w Polsce. (Climatic principles of water balances in Poland. In: Agroclimatic principles of land drainage in Poland). Ed. S. Bac. Warszawa, PWRiL: 76-133.

7. Doorenbos J., PruitT W.O., 1977. Guidelines for predicting crop water requirements. Irrigation Drainage Paper, 24. Rome, FAO: 1-144.

8. Dynowska L., Maciejewski M., 1991. Dorzecze Górnej Wisły. (Upper Vistula River Basin). Ed. I. Dynowska. Cz. I, II. Warszawa-Kraków, PWN: 1-341.

9. JAWORSKI J., 2004. Parowanie w cyklu hydrologicznym zlewni rzecznych. (Evaporation in the hydrological cycle of river basins). Warszawa, Pol. Tow. Geof.: 1-422.

10. KASPERSKA-WOŁOWICZ W., ŁABĘDZKI L., 2006. Climatic and agricultural water balance for grasslands in Poland using the Penman-Monteith method. Annales of Warsaw Agriculture University Land Reclamation, 37: 93-100.

11. KĘDZIORA A., 1995. Podstawy agrometeorologii. (Principles of agrometeorology). Poznań, PWRiL: $1-264$.

12. KowAnetZ L., 1999. Klimatyczny bilans wodny w zlewni Skawy, Raby i Dunajca. (Climatic water balance in the catchment areas of the Skawa, Raba and Dunajec rivers). Problemy Zagospodarowania Ziem Górskich PAN, 45: 29-39.

13. KUŹNIAR A., TwARDY S., 2001. Ocena potrzeb i niedoborów wodnych użytków zielonych w Polsce Południowej. (The estimation of grassland water requirements and deficits in the southern Poland). Problemy Zagospodarowania Ziem Górskich, 47: 29-41. 
14. KuŹNIAR A., 2010. Rozkład przestrzenny rolniczo-klimatycznego bilansu wodnego w dorzeczu górnej Wisły wyznaczonego z zastosowaniem metody Penmana-Monteitha (FAO-56). (The spatial distribution of agricultural-climatic water balance in the Upper Vistula River basin designated by applying the FAO-56 Penman-Monteith method). Woda Środowisko Obszary Wiejskie. Rozprawy naukowe i monografie, 28: 1-103.

15. ŁABĘDZKI L., 1995. Obliczanie ewapotranspiracji wskaźnikowej metodą Penmana-Monteitha. (Estimation of reference evapotranspiration by the Panman-Monteith method). Wiadomości Melioracyjne i Łąkarskie, 3: 128-130.

16. ŁABĘDZKi L., 1999. Przydatność wzoru Penmana-Monteitha do obliczania ewapotranspiracji wskaźnikowej i rzeczywistej użytków zielonych. (Usability of the Penman-Monteith equation for calculating reference and grassland evapotranspiration). Wiadomości IMUZ, 20, 2: 89-101.

17. ŁABĘDZKI L., 2006. Susze rolnicze. Zarys problematyki oraz metody monitorowania i klasyfikacji. (Agricultural drought. Outline of the issue, monitoring methods and classification). Woda Środowisko Obszary Wiejskie Rozprawy naukowe i monografie, 17: 1-107.

18. MiodUSZEWSKI W., 2006. Woda wirtualna - woda do produkcji żywności. (The virtual water water for food production). Gospodarka Wodna, 5: 173-178.

19. Misztal A., 2000. Możliwość wykorzystania metody Penmana-Monteitha do obliczania ewapotranspiracji wskaźnikowej na obszarze Małych Pienin. (Possible use of Penman-Monteith's method to calculate reference evapotranspiration in the small male Pieniny region). Problemy Zagospodarowania Ziem Górskich, 46: 63-72.

20. Monteith J.L., 1965. Evaporation and the environment. 19th Symposium. The Society for Experimental Biology. Swansea, Cambridge University Press: 205-234.

21. Ostrowski J., ŁabęDzki L., Kowalik W., Kanecka-Geszke E., Kasperska-Wolowicz W., SMARZYŃSKA K., TUSIŃSKI E., 2008. Atlas niedoborów wodnych roślin uprawnych i użytków zielonych w Polsce. (Atlas of the water deficits of cultivated plants and grasslands in Poland). Falenty, Wydaw. IMUZ: 1-19.

22. Penman H.L., 1948. Natural evaporation from open water, bare soil and grass. Proceedings of the Royal Society., 193: 120-145.

23. Roguski W., SARnacka S., DRUPKa S., 1988. Instrukcja wyznaczania potrzeb i niedoborów wodnych roślin uprawnych i użytków zielonych. (Instruction for estimation of the water requirements and deficiencies of field crops and grassland). Materiały Instruktarzowe, 66. Falenty, Wydaw. IMUZ: $1-90$.

24. SMITH M., 1992. CROPWAT. A computer program for irrigation planning and management. Irrigation Drainage Paper, 46. Rome, FAO: 1-126.

25. SzAJDA J., 2004. Dekadowe współczynniki roślinne do oceny ewapotranspiracji maksymalnej użytków zielonych na podstawie wzoru Penmana i plonu aktualnego. (Decade plant coefficients for the evaluation of the maximum evapotranspiration of grasslands further to Penman's equation and actual yield). Woda Środowisko Obszary Wiejskie, 4, 1(10): 79-90.

26. ThORNTHWAITE C.W., 1948. An approach toward a rational classification of climate. The Geographical Review, 38: 55-94.

27. Thornthwaite C.W., Mather J.R., 1955. The water balance. Publications in Climatology VIII, 1. New Jersey, Centerton: 1-86.

28. TWARDY S., 2008. Karpackie użytki rolne jako obszary o niekorzystnych warunkach gospodarowania. (Carpathian agricultural lands as Less Favoured Areas (LFA)). Woda Środowisko Obszary Wiejskie, 8, 2b(24): 191-202.

29. www.fao.org/nr/water/index.html 


\section{STRESZCZENIE}

\section{Ocena potrzeb wodnych runi pastwiskowej w Polskich Zachodnich Karpatach}

Słowa kluczowe: ewapotranspiracja wskaźnikowa, klimatyczny bilans wodny, pastwiska

Celem pracy było określenie ewapotranspiracji wskaźnikowej, potrzeb wodnych oraz klimatycznego bilansu wodnych pastwisk górskich w polskich Karpatach z zastosowaniem metody Penmana-Monteitha FAO-56 (ALLEN et al., 1998) . Osiągnięcie założonego celu zostało dokonane przez:

a) oszacowanie wartości ewapotranspiracji wskaźnikowej $E T_{o}$ oraz opracowanie rozkładu przestrzennego ewapotranspiracji wskaźnikowego $E T_{o}$ i elementów klimatycznego bilansu wodnego $\left(P-E T_{o}\right)$;

b) charakteryzowanie ewapotranspiracji wskaźnikowej oraz klimatycznego bilansu pastwisk górskich w Polskich Karpatach.

Poddano analizie dane meteorologiczne z 43 posterunków obserwacyjnych, pochodzących ze zbiorów Instytutu Meteorologii i Gospodarki Wodnej, a także ze Stacji Badawczej ITP w Jaworkach. Dane pochodziły z lat 1990-2005 i reprezentują zmienne warunki klimatyczne w polskich Karpatach. Wyniki badań przedstawiono w postaci map rozkładu przestrzennego, które wykonano metodą GIS ArcView. Przedstawiono następujące elementy: izolinie średnich: sum półroczy letnich $(\mathrm{V}-\mathrm{X})$, opadów atmosferycznych $P$, ewapotranspiracji wskaźnikowej $E T_{o}$, oraz klimatycznego bilansu wodnego $\left(P-E T_{o}\right)$.

W okresie półrocza letniego najmniejszymi wartościami ewapotranspiracji wskaźnikowej odznaczają się północne stoki Tatr (Zakopane - $433 \mathrm{~mm}$ ). Region Beskidu Zachodniego charakteryzuje się mniejszymi średnimi sumami ewapotranspiracji wskaźnikowej, wynoszącymi w okresie letnim od około $440 \mathrm{~mm}$ w Beskidzie Śląskim do $460 \mathrm{~mm}$ w Beskidzie Sądeckim. W Bieszczadach $E T_{o}$ w omawianym okresie letnim mieści się w zakresie od 460 do $480 \mathrm{~mm}$. Półrocze letnie charakteryzuje się dużym zróżnicowaniem przestrzennym średnich sum klimatycznego bilansu wodnego $\left(P-E T_{o}\right)$. Najwyższe nadmiary opadów $\left(P-E T_{o}\right)$ występują w partiach szczytowych Beskidu Żywieckiego $(400 \mathrm{~mm})$ oraz Tatr Polskich - ponad $700 \mathrm{~mm}$. Linia równowagi opadów atmosferycznych i ewapotranspiracji wskaźnikowej $\left(P=E T_{o}\right)$ przebiega wzdłuż granicy między Karpatami a Kotlinami Podkarpackimi. W Beskidzie Wyspowym notowane są nadmiary opadów od 100 do $250 \mathrm{~m}$. Kotliny śródgórskie charakteryzują się również znacznymi nadwyżkami opadów: Kotlina Żywiecka - $300 \mathrm{~mm}$, Orawsko-Nowotarska - poniżej $200 \mathrm{~mm}$, Sądecka - 150-200 mm i Doły Jasielsko-Sanockie - 0-100 mm. W Bieszczadach wskaźnik $\left(P-E T_{o}\right)$ wynosi od 150 do $300 \mathrm{~mm}$. 